\title{
First description of basaloid carcinoma of the canine mammary gland: case report
}

K.Y.R. Nakagaki https://orcid.org/0000-0002-0662-9577 Gonçalves org/0000-0001-7095-8431 R.M. Rocha https://orcid.org/0000-0002-4782-626X G.D. Cassali
https://orcid.org/0000-0002-5650-6743

[Primeira descrição do carcinoma basaloide da glândula mamária canina: relato de caso]

\author{
K.Y.R. Nakagaki ${ }^{1}$, A.B.B. Gonçalves ${ }^{1}$, R.M. Rocha ${ }^{2}$, G.D. Cassali ${ }^{1 *}$ \\ ${ }^{1}$ Instituto de Ciências Biológicas - ICB-UFMG - Belo Horizonte, MG \\ ${ }^{2}$ Universidade Federal de São Paulo - São Paulo, SP
}

\begin{abstract}
The objective of this case report was to describe histopathological and immunohistochemical characteristics of the first reported basaloid carcinomas in the canine mammary gland. Two bitches were treated for tumors in the mammary gland and underwent mastectomy. Microscopic evaluation of these tumors revealed epithelial cells arranged in a predominantly solid pattern with hyperchromatic peripheral cells arranged in a palisade pattern. Metastases in regional lymph nodes were found in both animals, and one bitch exhibited pulmonary metastasis. Immunohistochemistry revealed positive labeling for the basal cell markers cytokeratin 14 and p63. Histopathological and immunohistochemical findings led to diagnoses of basaloid carcinoma of the canine mammary gland with regional and distant metastasis.
\end{abstract}

Keywords: mammary gland, salivary gland, basaloid carcinoma, basaloid adenoma, solid carcinoma

\section{RESUMO}

O objetivo deste relato de caso é descrever as características histopatológicas e imuno-histoquímicas do primeiro relato de carcinoma basaloide na glândula mamária canina. Duas cadelas foram atendidas com tumores na glândula mamária e foram submetidas à mastectomia. A avaliação microscópica demonstrou células epiteliais arranjadas em um padrão predominantemente sólido, com células periféricas hipercromáticas, dispostas em paliçada. As duas apresentaram metástase em linfonodos regionais e uma delas metástase pulmonar. A imuno-histoquímica revelou marcação positiva para citoqueratina 14 e p63, marcadores de células basais. Achados histopatológicos e imuno-histoquímicos levaram ao diagnóstico de carcinoma basaloide da glândula mamária canina com metástase regional e a distância.

Palavras-chave: glândula mamária, glândula salivar, carcinoma basaloide, adenoma basaloide, carcinoma sólido

\section{INTRODUCTION}

Mammary tumors are the most frequent neoplasms in bitches and represent a heterogeneous group of neoplasms with respect to morphology and biological behavior (Cassali et al., 2014). Due to the difficulty of determining the origin of a specific type of cell in certain mammary tumors, the classification of canine mammary neoplasms is based mainly on histopathological patterns (descriptive morphology) and, to a lesser extent, on histogenetic classification (Gama et al., 2003).
In human medicine, basaloid carcinoma has been described in the salivary gland and is morphologically similar to its benign variant, basaloid adenoma; however, basaloid carcinoma exhibits an invasive growth pattern (Atula et al., 1993). In veterinary medicine, basaloid adenoma has been described in the mammary glands of dogs, with histological characteristics similar to those of basaloid adenoma in the human salivary gland (Kwapien et al., 1977; De Las Mulas et al., 2002).

Recebido em 27 de outubro de 2017

Aceito em 12 de novembro de 2018

* Autor para correspondência (corresponding author)

E-mail: geovanni.cassali@gmail.com 
Although basaloid adenoma in the canine mammary gland has been well characterized, its malignant variant has not previously been reported. Therefore, the purpose of this study was to describe the morphological and immunophenotypic characteristics of two cases of canine mammary basaloid carcinoma.

\section{CASE REPORT}

Tissue specimens from two bitches were collected in the laboratory of comparative pathology of Universidade Federal de Minas Gerais to perform histopathological examinations. The first animal (case 1) was a bitch of no definite breed and exhibited a mammary tumor with the clinical attributes of inflammatory carcinoma and metastasis in an inguinal lymph node and a lung. The second animal (case 2) was a Dachshund bitch with neoplasms in the right cranial abdominal mammary gland and right axillary lymph node.

Histopathological evaluation of the primary tumors revealed neoplastic masses composed of epithelial cells arranged in solid nests that varied in size and shape; these masses were delimited by thin connective stroma. The tumor cells had scant cytoplasm; the nuclei of the centrally arranged cells were slightly pale, and those of the hyperchromatic peripheral cells were arranged in a palisade pattern (Figure 1). Approximately three mitoses were observed in 10 fields at high magnification $(40 \times)$ in both cases. In case 1 , there were extensive areas of necrosis and fibrosis in addition to multifocal lymphatic invasion. Moderate fibrosis and squamous metaplasia were observed in case 2 . In accordance with the classification proposed by Elston and Ellis (1998), the histological grade of the primary tumors was categorized as grade II.

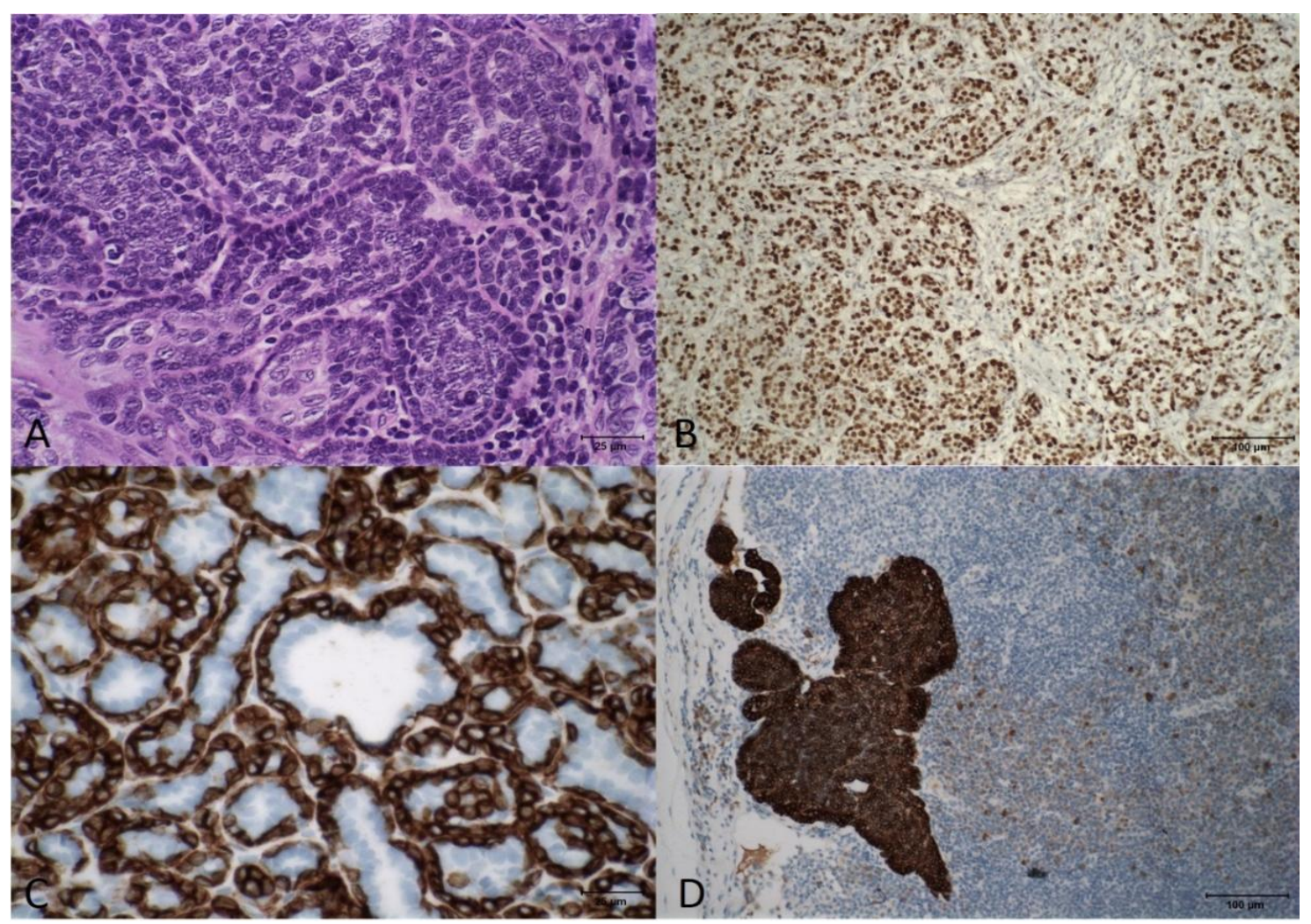

Figure 1. Bitch. Basaloid carcinoma. A. Mammary gland. Neoplastic epithelial cells arranged in solid nests with peripheral cells with hyperchromatic nuclei arranged in a palisade pattern. HE. B. Mammary gland. Immunohistochemical staining showing strong labeling for the cell proliferation antigen Ki67. Immunohistochemistry. C. Mammary gland. Primary tumor peripheral cells with intense positivity for cytokeratin 14. Immunohistochemistry. D. Lymph node showing epithelial proliferation, as evidenced by positive immunostaining for cytokeratin 14 . Immunohistochemistry. 
Histopathological evaluation of regional lymph nodes demonstrated macrometastasis in case 1 and micrometastasis in case 2; these metastases were characterized by epithelial cells forming solid nests, with palisade cells in the periphery. Pulmonary metastasis was observed in case 1 and was characterized by multifocal areas with coalescent malignant epithelial proliferation associated with necrotic foci, vascular invasion, and marked diffuse edema.
Histological sections of the primary tumors and the affected lymph nodes and lung were prepared for immunohistochemical analysis. A case of canine mammary basaloid adenoma was used for comparative purposes. Details regarding this analysis (Table 1) and its results (Table 2) are presented below.

Histopathological and immunohistochemical findings led to diagnoses of basaloid carcinoma with regional lymph node metastasis in both cases and pulmonary metastasis in case 1 .

Table 1. Target antigens and clones, dilutions, antigen retrieval methods, and incubation times and temperatures for immunohistochemical staining for Ki-67, transformation-related protein 63 (p63), cytokeratin 7 , cytokeratin 8 , and cytokeratin 14

\begin{tabular}{|c|c|c|c|}
\hline $\begin{array}{l}\text { Target Antigen } \\
\text { (Clone) }\end{array}$ & Dilution & Antigen Retrieval Method & Incubation Time (h)/Temperature \\
\hline $\begin{array}{l}\text { KI-67 } \\
\text { (MIB-1) }\end{array}$ & $1: 50$ & $\begin{array}{l}\text { Pressurized heat }\left(125^{\circ} \mathrm{C} / 2 \mathrm{~min}\right) \\
\text { with citrate buffer, } \mathrm{pH} 6.0\end{array}$ & Overnight $(18 \mathrm{~h}) / 4^{\circ} \mathrm{C}$ \\
\hline $\begin{array}{l}\text { p63 } \\
(4 \mathrm{~A} 4)\end{array}$ & $1: 100$ & $\begin{array}{l}\text { Water bath }\left(98^{\circ} \mathrm{C} / 20 \mathrm{~min}\right) \text { with } \\
\text { citrate buffer, } \mathrm{pH} 6.0\end{array}$ & Overnight $(18 \mathrm{~h}) / 4^{\circ} \mathrm{C}$ \\
\hline $\begin{array}{l}\text { CK7 } \\
\text { (OV-TL 12/30) }\end{array}$ & $1: 100$ & $\begin{array}{l}\text { Automated mode on the } \\
\text { Benchmark }^{\circledR} \text { platform }\end{array}$ & $30 \mathrm{~min} / 25^{\circ} \mathrm{C}$ \\
\hline $\begin{array}{l}\text { CK8 } \\
\text { (TS1) }\end{array}$ & $1: 100$ & $\begin{array}{l}\text { Automated mode on the } \\
\text { Benchmark }{ }^{\circledR} \text { platform }\end{array}$ & $30 \mathrm{~min} / 25^{\circ} \mathrm{C}$ \\
\hline $\begin{array}{l}\text { CK14 } \\
(\mathrm{LL} 002)\end{array}$ & $\begin{array}{l}\text { Ready to } \\
\text { use }\end{array}$ & $\begin{array}{l}\text { Automated mode on the } \\
\text { Benchmark }^{\circledR} \text { platform }\end{array}$ & $30 \mathrm{~min} / 25^{\circ} \mathrm{C}$ \\
\hline
\end{tabular}

Table 2. Immunohistochemical results for Ki-67, p63, cytokeratin 7, cytokeratin 8, and cytokeratin 14 for basaloid tumors

\begin{tabular}{lccccc}
\multicolumn{1}{c}{ Neoplasm } & $\begin{array}{c}\text { KI-67 } \\
(\%)\end{array}$ & $\begin{array}{c}\text { p63 } \\
(+/-)\end{array}$ & $\begin{array}{c}\text { CK7 } \\
(+/-)\end{array}$ & $\begin{array}{c}\text { CK8 } \\
(+/-)\end{array}$ & $\begin{array}{c}\text { CK14 } \\
(+/-)\end{array}$ \\
\hline $\begin{array}{l}\text { Basaloid adenoma } \\
\text { Case 1. Basaloid carcinoma }\end{array}$ & $5 \%$ & + & - & - & + \\
$\begin{array}{l}\text { Case 1. Basaloid carcinoma - } \\
\text { macrometastases in lymph nodes }\end{array}$ & $45 \%$ & + & - & - & - \\
$\begin{array}{l}\text { Case 1. Basaloid carcinoma - lung } \\
\text { metastases }\end{array}$ & $75 \%$ & + & - & - & + \\
$\begin{array}{l}\text { Case 2. Basaloid carcinoma } \\
\begin{array}{l}\text { Case 2. Basaloid carcinoma - } \\
\text { micrometastases in lymph nodes }\end{array}\end{array}$ & $50 \%$ & + & - & - & + \\
\hline
\end{tabular}

\section{DISCUSSION}

Mammary salivary glands are exocrine tubular acinar glands that can develop tumors that have similar morphological characteristics but differ in incidence and clinical behavior (Pia-Foschini et al., 2003).
Basaloid adenoma of the canine mammary gland closely resembles basaloid adenoma of the human salivary gland, and the immunophenotype of this tumor mimics that observed during the embryonic development of salivary gland tissues. Comparisons appear to indicate that basaloid proliferations of the mammary gland are 
relatively uncommon in humans and animals (Kwapien et al., 1977; De Las Mulas et al., 2002).

Basaloid carcinoma of the salivary gland is histologically similar to basaloid adenoma and is characterized by solid nests of cells and less often by trabecular or tubular structures. As observed in the two cases in this study, tumor cells have scant cytoplasm and strongly basophilic nuclei in a distinct palisade arrangement at the tumor periphery; these traits are characteristic of this histological type of tumor (Seifert et al., 1990, Farrell and Chang, 2007, Wilson and Robinson., 2015).

The primary tumors and metastases of case 1 and case 2 exhibited a basal immunophenotype, as demonstrated by positive labeling with a cytokeratin 14 antibody; this immunophenotype has been observed for basaloid adenomas of the canine mammary gland and basaloid neoplasms of the human salivary gland (De Las Mulas et al., 2002, Pia-Foschini et al. (2003) and Nagao et al., 2012). Positive immunostaining was also observed for p63, a selective marker for basal/myoepithelial cells (Edwards et al., 2004; Nagao et al., 2012). A ductal glandular pattern was not observed given negativity for cytokeratins 7 and 8 , for which positive staining is common in mammary neoplasms with this pattern (De Las Mulas et al., 2002; Pia-Foschini et al., 2003).

According to Seifert et al., (1990), the malignant potential of basaloid carcinoma is supported by local recurrence in $25 \%$ of cases and lymph node or lung metastasis in $10 \%$ of cases. Proliferative index and infiltrative growth are important features for differentiating basaloid adenoma from basaloid carcinoma. In cases 1 and 2, the proliferative indices determined using Ki-67 were $45 \%$ and $10 \%$, respectively; the mitotic count was three mitotic figures in 10 fields at high magnification $(40 \times)$ for both neoplasms.

For both analytical approaches, the proliferative indices for both neoplasms were higher than those observed for the examined basaloid adenoma, which exhibited 5\% immunolabeling by $\mathrm{Ki}-67$ and no mitotic figures in 10 fields at high magnification $(40 \times)$. These findings were compatible with previously reported results of mean Ki-67 immunolabeling of $3.3 \%$ and $15.5 \%$ for basaloid adenomas and basaloid carcinomas of the salivary gland, respectively (Nagao et al., 2012, Wilson and Robinson, 2015). In our study, the two mammary neoplasms led to regional lymph node metastasis in both cases and pulmonary metastasis in case 1 , confirming the malignant potential of these tumors.

In contrast to basaloid carcinomas of the salivary gland, tumors in the canine mammary gland of the observed histological type do not appear to exhibit a low degree of malignancy and a relatively favorable prognosis (Farrell and Chang, 2007). Further studies that include follow-up data for patient survival are necessary to better understand the behavior of neoplasms of this new histological type.

\section{CONCLUSION}

Histological type is regarded as an independent prognostic factor for canine mammary neoplasms. Therefore, establishing criteria for and recognizing and reporting various histological subtypes of mammary tumors in dogs is essential for improving the appropriateness and effectiveness of treatment for such tumors.

\section{REFERENCES}

ATULA, T.; KLEMI, P.J.; DONATH, K. et al. Basal cell adenocarcinoma of the parotid gland: a case report and review of the literature. $J$. Laryngol. Otol., v.107, p.862-864, 1993.

CASSALI, G.D.; LAVALLE, G.E.; FERREIRA, E. Consensus for the diagnosis, prognosis and treatment of canine mammary tumors-2013. Braz. J. Vet. Pathol., v.2, p.38-69, 2014.

DE LAS MULAS, J.M.; ORDÁS, J.; MILLÁN, M.Y. et al. Spontaneous basaloid adenomas of the mammary gland in four dogs: clinicopathologic and immunohistochemical features. Vet. Pathol., v.39, p.739-743, 2002.

EDWARDS, P.C.; BHUIYA, T.; KELSCH, R.D. Assessment of p63 expression in the salivary gland neoplasms adenoid cystic carcinoma, polymorphous low-grade adenocarcinoma, and basal cell and canalicular adenomas. Oral Surg., Oral Med., Oral Pathol., Oral Radiol., Endod., v.97, p.613-619, 2004. 
ELSTON, C.W.; ELLIS, I.O. Assessment of histological grade. In: (Eds.). Systemic pathology: the breast. England: Churchill Livingstone, 1998. p.365-384.

FARRELL, T.; CHANG, Y.L. Basal cell adenocarcinoma of minor salivary glands. Arch. Pathol. Lab. Med., v.131, p.1602-1604, 2007.

GAMA, A.; ALVES, A.; GARTNER, F.; SCHMITT, F. p63: a novel myoepithelial cell marker in canine mammary tissues. Vet. Pathol., v40, p.412-420, 2003.

KWAPIEN, R.P.; GILES，R.C.; GEIL，R.G.; CASEY, H.W. Basaloid adenomas of the mammary gland in beagle dogs administered investigational contraceptive steroids. J. Nat. Cancer Instit., v.59, p.933-939, 1997.

NAGAO, T.; SATO, E.; INOUE, R. et al. Immunohistochemical analysis of salivary gland tumors: application for surgical pathology practice. Acta Histochem. Cytochem., v.45, p.269-282, 2012.
PIA-FOSCHINI, M.; REIS-FILHO, J.S.; EUSEBI, V.; LAKHANI, S.R. Salivary glandlike tumours of the breast: surgical and molecular pathology. J Clinic. Pathol., v.56, p.497-506, 2003.

SEIFERT, G.; BROCHERIOU, C.; CARDESA, A.; EVESON, J.W. WHO International histological classification of tumours tentative histological classification of salivary gland tumours. Pathol. Res. Practic., v.186, p.555-581, 1990.

WILSON, T.C.; ROBINSON, R.A. Basal cell adenocarcinoma and basal cell adenoma of the salivary glands: a clinicopathological review of seventy tumors with comparison of morphologic features and growth control indices. Head Neck Pathol., v.9, p.205-213, 2015. 